\title{
人造繊維のアルカリ処理による内部構造の変化
}

緇稚工業試験所万正

\section{CHANGE IN FIBRE STRUCTURE OF REgENERATED CELLULOSE FIBRES BY TREATMENT WITH CAUSTIC SODA SOLUTIONS.

\author{
By Tadashi Yurugi
}

(The Textile Research Institute of Japan. 4 Sawatari, Kanagawa, Yokohama, Japan.)

Changes in fibre structure of regenerated cellulose fibres such as degree of crystallinity and lateral order and cross-sectional shape, by treatment with aqueous alkali of various concentrations have been investigated experimentally.

Rayons of two types were used and compared; fibre $S$, ordinary viscose sayon having irregular section and non-uniform distribution of lateral order, Fibre $\mathrm{X}$, special viscose rayon having uniform round section and uniform single-peak lateral order distribution.

Both fibers showed increases in crystallinity, after swelling and deswelling, but the magnitude of the change in low ordered fibre (S) was much greater. The skin effect of this fibre disappeared and the distribution of lateral order shifted to highly ordered level and showed similar curve to that of Fibre X.

Changes in physical properties of fibres by swelling treatment were also observed, and discussed on the relation between fibre structures and mechanical properties. It was concluded that physical properties of Fibre $\mathrm{X}$ are closely associated with crystalinity and orientation, whereas those of Fibre $S$ are much more markedly effected by the skin-core structure. (Received 23. 7. 1955)

\section{緒訔}

再生繊維素瀻維をアルカリで処理すると，その膨潤 作用により天然緎維素織維の場合とは反対に結晶性が 向上することが，前田，1) Hermans, ${ }^{2)}$ Rosevear ${ }^{3)}$ 等に よって観察されれている。の現象について詳細な研究 を行い，結晶領域の大さ，安定性すなわち結晶性配列 度 (Lateral Order) の分布状態の変化, さらに繊維組 䋘艘造の变化等记つき，2，3 の知見を得たのでその 結果を報告する。

\section{実験およぴ考察}

\section{1. 实 娩 試 料}

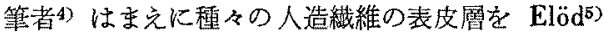
の考案した不均一酶酸化虽皮法で取り除き，剥皮前後 の Lateral Order の分布曲線を比較し，人造緎維は 一般に結晶性の高い中心部之，結晶性の少る表皮圓か らなること，その結果は必ずしるメタクロマジーによ る顕微鏡観察の結果とは一致せず，内外周 Leteral
Order 分布のほぼ同一の緎維は，紡系過程に括いて， 㠜固と延伸を別個に行わせる場合に限り得られること を明らかにした。本研究試料には，内外構造差の著る しい Müller 浴炕よる市販人造䋐維 $(S)$ と，内外均一

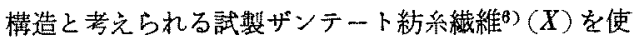
用した。雨織維の主なる物理的性質はつぎの通りであ る。

第 1 表 試料瀻維の物理的性質

\begin{tabular}{|c|c|c|c|c|}
\hline \multicolumn{2}{|r|}{ 試 } & 料 & $S$ & $X$ \\
\hline 緎 & & 度 (d) & 1.48 & 2.87 \\
\hline 乾 & 強 & 度 $(g / d)$ & 2.77 & 3.03 \\
\hline 湿 & 強 & 度 $(\mathrm{g} / \mathrm{d})$ & 1.92 & 2.21 \\
\hline 湿 & 乾 強 & 比 $(\%)$ & 69.2 & 72.6 \\
\hline 乾 & 伸 & 度 $(\%)$ & 16.1 & 5.8 \\
\hline 湿 & 伸 & 度 $(\%)$ & 24.8 & 6.1 \\
\hline
\end{tabular}

\section{2、アルカリ処理による微結晶構造の変化}

アルカリ处理の効果は，フルカリの湴度、処理温度、 処理時間括よび穢維の緊張の有無等によって異なるが、 
本報に括いては，アルカリ濃度のみを変化させ，他の 条件はすべて同一にし，無緊張状態で処理した場合の 結果を述へる。すなわち風㲦陚料を約 50 倍量の $30^{\circ} \mathrm{C}$ の $2 \sim 8 \%$ 苛性ソーダ溶液中に5 分間浸漬, 水洗後 1 \%酷酸に5 分間浸责，ついで水洗，風勃した。各处理 試料は酸加水分解・アルカリ分別溶解法 (3)，江上り， その Lateral Order の分布状態を求めた。第 1 図は 実験結果に基つく推定分布曲線を示したものである。

(図中の数字は処理液 $\mathrm{NaOH}$ の濃度 (\%) を示す) 第 2 表には，前報4) 同様, 加水分解残渣の $8 \%$ 苛泩ソー ダ不溶部分を高結晶性領域として示した。

実験の結果，両㵶維ともにアルカリの䟴度の增加に

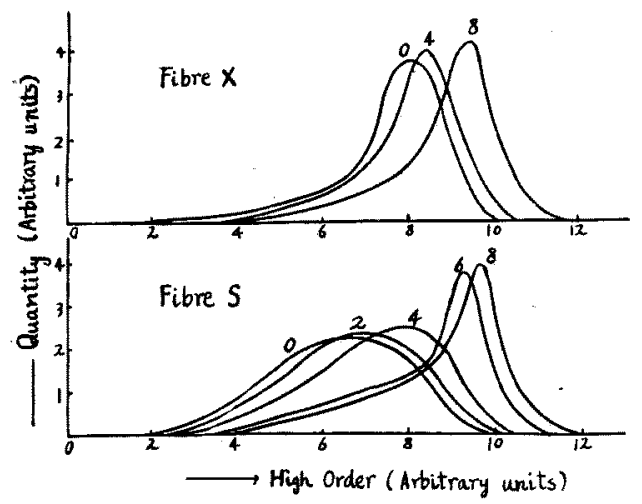

Fig. 1 Tentative Lateral Order Distribution Curves. $0 ;$ Original Fibre, 2,4,6,8; Alkali-treated Fibre.
第 2 表 フルカリ処理瀻維の高結晶性項域量

\begin{tabular}{|c|c|c|c|c|}
\hline 処理液 & $\begin{array}{l}\mathrm{NaC} \\
(\%)\end{array}$ & & $S$ 一緎維 & $X$-瀻維 \\
\hline 原 & 縅 & 維 & 21.4 & 47.0 \\
\hline & 2 & & 22.7 & 47.6 \\
\hline & 4 & & 38.0 & 57.2 \\
\hline & 6 & & 59.2 & 64.9 \\
\hline & 8 & & 60.8 & 72.3 \\
\hline
\end{tabular}

伴い結晶領域の著るしい拗大が認められる。しかしる ともと高結晶性である $X$ 䋐維の変化は $S$ 䋘維に比し て少ない。これは処理前すでに相当安定な凝集状態に あるためと思われる。また第 1 四の分布曲線の形の変 化す両瀻維で著るしく異なり，处理前に見られる相違 は，処理戍のアルカリ濃度の增加とともに少なくなり，

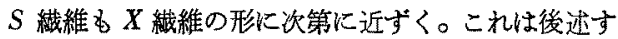
る断面組䋘構造の変化に関連するるのと思方九る。

\section{3、アルカリ処理による機械的性質の变化}

前項の実験で得た各処理試料の主要な機械的性質を 測定し，第 3，4 表に示した。

実験の結果，アルカリ処理による徽細構造の変化は， 機械的性質にる反映したすのと思われ，著るしい変化 が観察される。その变化る両絾維間に甚だしい相違が ある。まず普通の人造瀻維 $(S)$ について見ると，処理

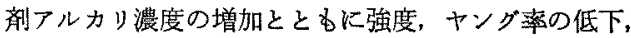
伸度の增大，湿乾強度比の隇少が認められる。この変 化は，とくにアルカリ濃度 4 〜 6\%間で急激に起り， 第 1 図の Lateral Order 分布曲線の形の賕わる瀑度と

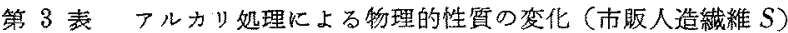

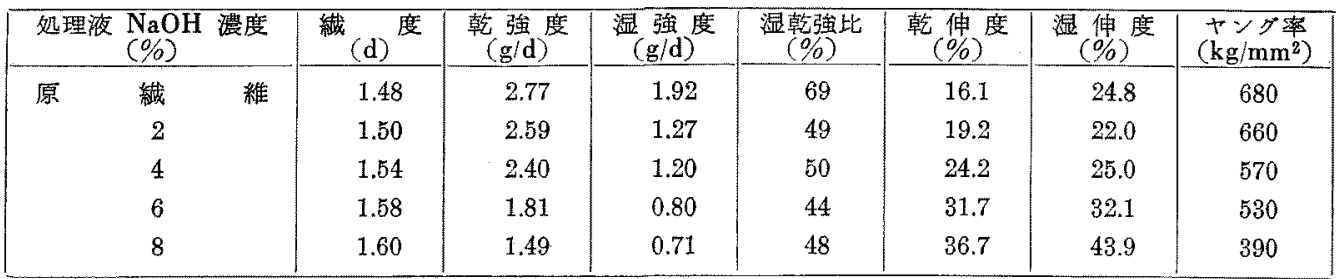

第 4 表 アルカリ処理による物理的性質の梁化（ザンテート法人造紷維 $X$ )

\begin{tabular}{|c|c|c|c|c|c|c|c|c|c|}
\hline 処理液 & $\begin{array}{l}\mathrm{NaO} \\
(\%)\end{array}$ & 要度 & ${ }^{\text {緎 }}(\mathrm{d})^{\text {度 }}$ & $\begin{array}{c}\text { 乾 }(\mathrm{g} / \mathrm{d} / \mathrm{L}) \\
\end{array}$ & 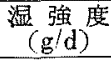 & $\begin{array}{c}\text { 湿乾強比 } \\
(\%)\end{array}$ & 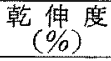 & $\begin{array}{c}\text { 湿 }(\%) \\
\end{array}$ & $\begin{array}{l}\text { オング率 } \\
\left(\mathrm{kg} / \mathrm{mm}^{2}\right)\end{array}$ \\
\hline \multirow[t]{5}{*}{ 原 } & 織 & 䧽 & 2.87 & 3.03 & 2.21 & 72.6 & 5.8 & 6.1 & 1640 \\
\hline & 2 & & 2.98 & 2.95 & 1.94 & 65.7 & 6.0 & 6.9 & 1780 \\
\hline & 4 & & 3.16 & 2.72 & 2.15 & 79.1 & 9.6 & 10.2 & 1540 \\
\hline & 6 & & 3.25 & 2.64 & 2.41 & 91.3 & 9.3 & 19.1 & 1200 \\
\hline & 8 & & 3.49 & 1.98 & 1.56 & 78.7 & 12.5 & 18.1 & 970 \\
\hline
\end{tabular}


一致していることは舆味のある結果である。

つぎに均一㭠造の紻維 $(X)$ Kついて見ると，アルカ リ濃度の增加に伴って，伸度の增大，ヤング率の低下 している処は $S$ 瀻維と同檨であるが，强度の変化につ いては全く趣が異なり，乾燥強度の低下す $S$ 瀻維に比 して少なく，湿潤強度は $6 \% \mathrm{NaOH}$ 究でとんど变 化なく、したがって湿乾強度比は著るしく增大してい る。 $8 \% \mathrm{NaOH}$ 処理によりはじめて湿潤強度, 湿乾 強度比が低下している。この纎維は緎度が著るしく増 大し，アルカリ処理により取䑿したことがわかる。S 䋐維においては，ほとんど繊度の变化は諗められない。 $X$ 緎維は内外風とともに配列性梗めて高く, 膨潤, 脱 感潤により容易に収缩し得るるのと思われる。この㵶 維の機械的性犋の变化，ヤング率の低下，伸度の堌大， 湿乾強度比の堌大等は, 結晶珄の向上と配列性の低下 の両效果として期待される結果である。適当なアルカ り謴度をえらべば，これらの効果性緎維の機械的性質 の向上K著るしく寄与し，本実娩に和いても，強度， 伸度いずれも比較的高くしかも湿乾強度比䄪 $90 \%$ の あのが得られている。これに反し $S$ 纎維においては， その著大な結晶化も何等織維性能の向上に役立ってい ないものと思われる。

\section{4. アルカリ姏理による断面組緎構造の変化}

断面組織㩐造差の大きい縕維(S)につき，フルカリ 処理によるその变化を観察した。

まず，前実験の各処理唁料をダイレクト・スカーレ ットで染色し，断面を顕微鏡で観察した。その結果

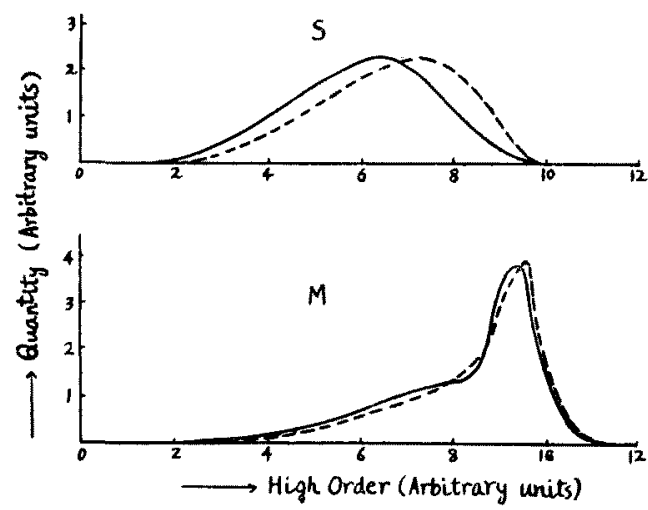

Fig. 2 Tentative Structural Difference between Skin + Cone in Regenerated Callulose Fibres. S; Original Fibne, $27.0 \%$ Removed. $M$; Mencerijed Fibre, $25.8 \%$ Removed. (-skin, --.--core)

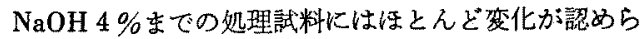
れないが，6\%以上の処理を受けたるのは全く異なり， いかゆるスキン周は消失，断面は一樣に染色され，輪

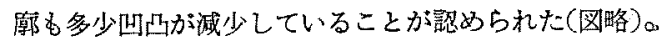

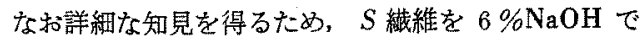
$20^{\circ} \mathrm{C}$ において5分間処理したるの(Mとする)につき。 不均一酷酸化法で表皮層を取り除き，剩皮部分(スキ ン屡) および残存部分 (中心部) の Lateral Order の 分布劰線を求わた。第 2 図に原䋗維の結果ととる示 した。また両繊維のスキン層，中心部の高結晶性領域 量を第 5 表に示した。

第 5 表 スキン層，中心部の高結晶性颂域量

\begin{tabular}{|c|c|c|c|c|c|}
\hline \multirow{2}{*}{ 試 } & \multirow{2}{*}{ 料 } & \multicolumn{2}{|c|}{ 原紻維 $(S)$} & \multicolumn{2}{|c|}{$\begin{array}{l}\text { 丁ルカリ桑 } \\
\text { 理㵶維 }(M)\end{array}$} \\
\hline & & $\begin{array}{l}\text { ス } \\
\text { ン層 }\end{array}$ & $\begin{array}{l}\text { 中心 } \\
\text { 部 }\end{array}$ & 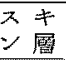 & $\begin{array}{l}\text { 中心 } \\
\text { 部 }\end{array}$ \\
\hline 高結奛性 & 量 $(\%)$ & 10.4 & 25.5 & 65.9 & 62.8 \\
\hline 剩 & 量 $(\%)$ & \multicolumn{2}{|c|}{27.0} & \multicolumn{2}{|c|}{25.8} \\
\hline
\end{tabular}

この実娩結果からも，断面權造に著るしい変化が起 ったことがわかる。アルカリの敳潤作用により組織は 均一化さ机，スキン層，中心部の Lateral Order 分布 曲線ははとんど一致している。スキン層, 中心層とる に結晶性が向上しているが，結晶性の多るスキン圈の 変化は中心部に比して罍かに大きく，処理後の高結晶 性頒域量は惊ぼ同じ值を示している。この变化(スキ ン層の消失) るアルカリ濃度 4 〜 $6 \%$ 以上の処理で起 り，前実験で知見した Lateral Order の形，特よび物 理的性質の急变する霞度と一致する。スキン層, 中心 部 2 層加らなる瀻維の機械的性質，とくに強度的性質 等は主としてスキン層の棈造に依存するあのと考えら れる。したがってアルカリ処理によるスキン層の消隇

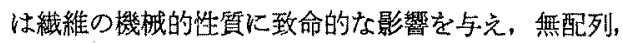
無組維状態では結晶㤬の向上る，強度，耐水性の增加 には何等寄与しないるのと思われる。

\section{5. アルカリ処理による膨潤性の変化}

試料 $(S)$ Kつき, アルカリ処理による機械的性質以 外の $2 ， 3$ の性質の变化を調べ結果を第 6 表に示した。 膨潤度は $20^{\circ} \mathrm{C}$ の水中に 1 時間浸漬後, 20 分間遠心 分離器で脱水し $(3000 \mathrm{rpm})$, 残存する水の量を測定 した。

鼔潤度 $(\%)=\frac{\text { 吸水試料の重量一緦乾試料の重量 }}{\text { 緢幛試料の重量 }} \times 100$ 次表の值は 4 回の実験の平均值である。 
第 6 表 アルカリ処理に上る性質の夜化

\begin{tabular}{|c|c|c|c|c|c|}
\hline \multicolumn{3}{|c|}{ 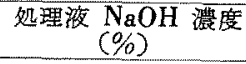 } & $\begin{array}{c}\text { 膨潤度 } \\
(\%)\end{array}$ & $\begin{array}{c}\text { 吸溜昜 } \\
\end{array}$ & $\begin{array}{l}\text { 染料吸着 } \\
\text { 量 }(\%)\end{array}$ \\
\hline \multirow[t]{5}{*}{ 原 } & 䌖 & 維 & 101 & 14.5 & 0.99 \\
\hline & 2 & & 104 & 14.6 & 1.08 \\
\hline & 4 & & 100 & 14.3 & 1.20 \\
\hline & 6 & & 96 & 13.2 & 1.41 \\
\hline & 8 & & 92 & 13.4 & 1.39 \\
\hline
\end{tabular}

四湿量は $20^{\circ} \mathrm{C}$ ， RH $65 \%$ 平衡值を求めた。

染料㹄着量は Congored $5 \%, \mathrm{Na}_{2} \mathrm{SO}_{4} 10 \%$ の染浴 (浴比 100 倍)，温度 $\left(98 \sim 100^{\circ} \mathrm{C}\right) 飞 30$ 分間浸漬，染 色し残液を 5 倍に5すめて比色，吸着量（緎維汇対す る\%)を求めた。

上表の結果，膨潤度，吸湿量はアルカリ処理により 減少している。結晶坐の向上によるためと思われる。 しかし䀝潤度の変化は極めて灌かである。染料吸着量 は逆に增大している。これらの性質の変化子㵶維の組 織榡造に大きな变化の起るフルカリ濃度 $6 \%$ 附近を境 として著るしくなっている。

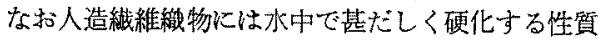
があり、そのために染色, 仕上げ等の操作を困難とす ることがよく知られている。その理由として，吸水脰 潤度か過大であるためと言われている。実験の結果, この水中硬化の現象る6\%以上の菏性ンーダ処理によ り除き得ることが認められた。乙か乙第 6 表の結果か

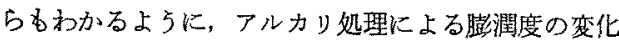
は極めて僅少であり，この膨潤度の僅かの増加によっ て水中硬化が起るとは考克られない。勿論大量の水を 吸収することるとの 1 つの原因であるらが，むしち断 面の形態，組織構造の不均一性等汇より大きな原因が あるすのと推察される。

\section{総括}

1.2種の人造䋐維，すなわちスキン㬝，中心部の

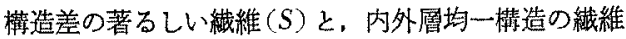
$(X)$ を実験試料として，アルカリ膨潤処理による徽結 晶構造，断面組織招よび機械的性質の变化を観察，両 緎維につき比皎した。

2. 両䋐維とるとアルカリ処理により, 結晶性の向 上が認められるが，もとると低結晶性の $S$ 䋐維の結晶 化はより著るしくとくにスキン層に执いて甚たしい。 ある濃度以上の処理を受けた織維は、スキン層，中心 部の Lateral Order 分布状態はほとえど同一となり， 巨視的炕もスキン㬝は消失すること学認めだ。

3. アルカリ処理とよる機械的性質の变化子両絾維 に著るしい相違があり， $X$ 緘維执いては，伸度の增 大，耐水性の向上が認められるが，S織維においては， 強度, 而水性は一方的に低下し, 結晶性向上の寄与は 全く認められない。S結維の性質の変化は主としてス キン層の消失に原因するものと推察した。

\section{文献}

1) 前田, 本誌, 4, 40 (1948)

2) P. H. Hermans, A. Weidinger; J. Polymer Sci, 4, 317 (1949)

3) W. E. Rosevear; Ind. Eng. Chem., 44, 168 (1952)

4）著者；工化投稿中

5) E. Elöd, H. G. Fröhlich ; Text. Res. J., 18, 487 (1948)

6) 著者；瀻工試報，28，34 (1954)

7) 著者; 工化，58，27 (1955)

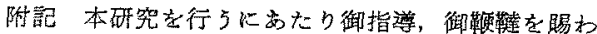
った当所，成田所長，生鲍部長飞感謝の意を表

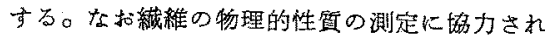

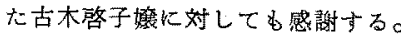

